\title{
Optimalisasi Pengoperasian Pompa Bahan Bakar Bertekanan Tinggi Terhadap Kelancaran Operasional Motor Bantu di MT. Soechi Anindya
}

\author{
Buswan $^{1}$, Imam Fahcruddin ${ }^{2}$, Genda Arfathulhaq ${ }^{3}$ \\ ${ }^{1,2,3}$ Prodi Teknika \\ Sekolah Tinggi Ilmu Pelayaran, Jakarta \\ Jl. Marunda Makmur No. 1 Cilincing, Jakarta Utara. Jakarta 14150
}

\begin{abstract}
Abstrak
Untuk menunjang operasional kapal diperlukan motor bantu berupa generator untuk menghasilkan listrik sehingga bisa digunakan untuk berbagai keperluan penunjang operasi mesin induk. Masalah yang sering muncul adalah kerusakan pompa bahan bakar bertekanan tinggi pada motor bantu dan ketersediaan suku cadang pompa bahan bakar. Penelitian ini bertujuan untuk mengetahui penyebab kerusakan pompa bahan bakar bertekanan tinggi pada motor bantu dan mengetahui bagaimana mengoptimalkan ketersediaan suku cadang. Metode Pendekatan yang digunakan deskriptif kualitatif. Dari hasil penelitian diperoleh kesimpulan bahwa Terjadinya kerusakan pompa bahan bakar bertekanan tinggi diakibatkan oleh kurangnya perawatan. Kerusakan pompa bahan bakar bertekanan tinggi mengakibatkan turunnya kinerja dari pompa tersebut, sehingga terjadi penurunan tekanan bahan bakar yang masuk kedalam silinder yang menyebabkan tidak optimalnya kinerja dari motor bantu. Kurangnya ketersediaan suku cadang di atas kapal diakibatkan oleh keterlambatan pengiriman suku cadang dari perusahaan kepada kapal, dan kurangnya koordinasi dari pihak kapal dan perusahaan pemilik kapal.
\end{abstract}

Copyright $\odot 2020$, Prosiding Seminar Pelayaran dan Riset Terapan

Kata Kunci: pompa bahan bakar, motor bantu, optimalisasi

Permalink/DOI : https://doi.org/10.36101/pcsa.v2i1.135

\section{PENDAHULAN}

Transportasi merupakan kegiatan pemindahan barang muatan dan penumpang dari suatu tempat lain (Salim, 2006). Dikatakan juga bahwa transportasi menjadi dasar untuk pembangunan ekonomi dan perkembangan masyarakat serta pertumbuhan industralisasi. Transportasi dalam fungsinya sebagai unsur penunjang dan perangsang memiliki peranan yang sangat besar dalam pembangunan, baik dibidang ekonomi, politik, sosial budaya maupun pertahanan dan keamanan (Tamin, 2000). Selain itu, peranan transportasi sangat penting dalam pembangunan wilayah, khususnya Indonesia yang menuntut penyediaan jasa transportasi kian meningkat baik darat, laut dan udara dalam jumlah maupun mutunya

Menurut Undang- Undang Nomor 17 tahun 2008 tentang Pelayaran, kapal adalah kendaraan air dengan bentuk dan jenis tertentu, yang digerakkan dengan tenaga angin, tenaga mekanik, energi lainnya, ditarik atau ditunda, termasuk kendaraan yang berdaya dukung dinamis, kendaraan di bawah permukaan air. Serta alat apung dan bangunan terapung yang tidak berpindah-pindah. Dikarenakan dapat mengangkut suatu muatan yang lebih besar dibandingkan alat transportasi lainnya.

Seiring dengan perkembangannya kapal laut banyak mengalami berbagai macam perubahan, mulai dari bentuk konstruksi, maupun tenaga penggeraknya. Untuk tenaga penggerak kapal laut di zaman modern ini telah banyak mengalami kemajuan. Selain itu juga terdapat permesinan bantu yang berguna untuk mendukung kerja dari penggerak utama. Bila semua permesinan yang ada di atas kapal tidak dapat saling mendukung, maka dapat dipastikan dapat menghambat pengoperasian kapal.

Lancarnya operasi kapal, tentunya tidak lepas dari personil yang menangani motor induk, motor bantu, pesawat-pesawat bantu maupun suku cadangnya, karena merupakan satu sistem yang berfungsi untuk menunjang kelancaran operasi kapal. Motor induk sebagai penggerak utama kapal harus mendapat perhatian atau perawatan secara terencana dan berkelanjutan, agar kapal selalu berada di lautan dan dapat mengangkut serta memindahkan barang dari satu pelabuhan ke pelabuhan yang lain dan mesin-mesin selalu berjalan lancar dan tahan lama meskipun dalam kondisi cuaca yang buruk. 
Salah satu penunjang operasi kapal laut ialah motor bantu (generator) yang berfungsi untuk menghasilkan listrik dengan cara mengubah energi gerak menjadi energi listrik, sehingga bisa digunakan untuk berbagai keperluan penunjang operasi mesin induk, bahkan menunjang operasional kapal itu sendiri. Demi kelancaran operasional motor bantu juga banyak didukung oleh beberapa peralatan penunjang, salah satunya adalah pompa bahan bakar bertekanan tinggi. Pompa bahan bakar bertekanan tinggi merupakan suatu alat untuk menyalurkan masuk banyaknya bahan bakar ke rumah katup bahan bakar (pengabut) dan menyemprotkan bahan bakar ke silinder melalui lubang-lubang kecil sehingga membentuk molekul-molekul kecil (spray), sehingga terjadi proses pembakaran di dalam silinder. Di dalam peninjauan kinerja dan perbaikan terhadap pompa bahan bakar bertekanan tinggi, sebelumnya harus mengerti bagaimana cara mengatasi jika pembakaran tidak sempurna dari motor diesel di atas kapal.

Selama melakukan pengamatan ditemukan permasalahan bahwa kurangnya tekanan, bahkan tidak adanya bahan bakar yang masuk ke dalam silinder sehingga tidak sempurnanya pembakaran bahkan tidak ada pembakaran di dalam silinder, yang dapat diketahui dari suhu gas buang tiap-tiap silinder. Hal ini terjadi pada saat kapal berlabuh di Tanjung Uban pada tanggal 21 Oktober 2016. Setelah diadakan pengecekan terhadap pompa bahan bakar bertekanan tinggi, ditemukan beberapa penyebab terjadinya permasalahan tersebut, diantaranya patahnya delivery valve spring yang menyebabkan tidak terpompanya bahan bakar yang dialirkan ke dalam alat pengabut bahan bakar (injektor), terjadinya keausan pada plunyer dan plunyer barrel sehingga tekanan bahan bakar yang masuk ke dalam alat pengabut bahan bakar sangat minim.

Dalam permasalahan ini, peneliti mengasumsikan bahwa kerusakan tersebut dapat terjadi karena minimnya perawatan terhadap pompa bahan bakar bertekanan tinggi pada motor bantu, serta kondisi suku cadang yang tidak sesuai dengan yang di instruksikan pada buku petunjuk, dan suku cadang tersebut tidak terpenuhi di kapal.

Berdasarkan hal tersebut peneliti menguraikan identifikasi masalah, yaitu:

1. Patahnya delivery valve spring yang mengakibatkan tidak adanya bahan bakar yang masuk atau terpompa ke dalam silinder.

2. Tidak sempurna bahkan tidak terjadi pembakaran di dalam silinder.

3. Kurangnya ketersediaan suku cadang pompa bahan bakar bertekanan tinggi di kapal.
4. Terjadinya keausan pada plunyer dan plunyer barrel.

5. Kerusakan pompa bahan bakar bertekanan tinggi pada motor bantu nomor 2 .

Perawatan yang kurang teratur, pengawasan yang kurang baik pada pompa bahan bakar bertekanan tinggi akan mengakibatkan kerja dari suatu mesin sering terjadi gangguan. Oleh karena itu peneliti merumuskan masalah-masalah sebagai berikut :

1. Apa penyebab kerusakan pompa bahan bakar bertekanan tinggi pada motor bantu?

2. Apa yang menyebabkan kurangnya ketersediaan suku cadang pada pompa bertekanan tinggi?

Kemudian tujuan dilaksanakannya penelitian ini yaitu:

a. Untuk mengetahui penyebab kerusakan pompa bahan bakar bertekanan tinggi pada motor bantu.

b. Untuk mencari solusi yang tepat dalam mengatasi masalah dalam ketersediaan pompa bahan bakar bertekanan tinggi.

\section{METODE}

Metode Pendekatan yang digunakan dalam penelitian ini adalah metode pendekatan deskriptif kualitatif. Dalam memperoleh data peneliti menggunakan teknik pengumpulan data berupa observasi. Observasi adalah pengumpulan data berupa informasi berdasarkan pengamatan langsung oleh peneliti di MT. Soechi Anindya. Kemudian motor bantu yang digunakan di kapal adalah YANMAR 5MAL dengan kondisi:
Merk : Yanmar diesel engine
Type :5-MAL (4stroke cycle)
Jumlah silinder : 5
Bore $\quad: 200 \mathrm{~mm}$
Stroke $\quad: 240 \mathrm{~mm}$
Max conrating : $200 \mathrm{HP}$
Putaran : $900 \mathrm{RPM}$

\section{HASIL DAN PEMBAHASAN}

Motor bantu memiliki komponen-komponen yang mendukung kinerja motor bantu tersebut. pompa bahan bakar bertekanan tinggi merupakan bagian yang sangat penting dari suatu mesin diesel. Dengan demikian menjaga dan mempertahankan agar pompa bahan bakar bertekanan tinggi ini dapat beroperasi dengan baik, serta untuk mencegah terjadinya kerusakan. Sehingga hasil yang didapat dari proses injeksi bahan bakar sampai dengan terjadinya pembakaran di dalam silinder, maka dibutuhkan suatu kualitas sumber daya manusia untuk merawat dan mengawasinya.

Masinis di kapal dalam hal perencaan 
perawatan yang benar dan sesuai dengan prosedur-prosedur perawatan yang telah ditentukan oleh maker (pembuat mesin), akibat dari pelaksanaan perawatan yang tidak sesuai terhadap pompa bahan bakar bertekanan tinggi belum dilakukan sesuai prosedur, sehingga dapat menimbulkan masalah, gangguan atau kerusakan pada komponen tersebut yang mengganggu kegiatan operasional kapal.

1. Terjadinya kerusakan pompa bahan bakar bertekanan tinggi pada motor bantu.

Adapun permasalahan yang ditemukan peneliti di MT. Soechi Anindya antara lain terjadi pada saat kapal berlabuh di Tanjung Uban tanggal 21 Oktober 2016. Ketika Peneliti melakukan observasi pada temperatur gas buang motor bantu yang beroperasi dalam hal ini motor bantu yang beroperasi adalah motor bantu nomor 2, Peneliti menemukan ketidaksesuaian gas buang pada salah satu silinder dimana temperatur gas buangnya dibawah angka normal yaitu pada silinder nomor 5 dengan temperatur $40^{\circ} \mathrm{c}$, sedangkan nilai normalnya ialah $150-220^{\circ} \mathrm{C}$.

Peneliti juga melakukan observasi temperatur rumah pompa bahan bakar bertekanan tinggi dengan menggunakan infrared thermometer (lampiran XIII), didapati suhu rumah pompa tersebut yaitu $98^{\circ} \mathrm{c}$ sedangkan nilai normalnya ialah $38-45^{\circ} \mathrm{c}$. Terjadinya kerusakan pompa bahan bakar bertekanan tinggi tersebut menyebabkan motor bantu nomor 2 tidak beroperasi dengan optimal.

2. Kurangnya ketersediaan suku cadang pompa bahan bakar bertekanan tinggi.

Peneliti menemukan pada saat obeservasi di atas kapal tentang pengadaan suku cadang, bahwa ketersediaan dan pengadaan suku cadang khususnya pompa bahan bakar bertekanan tinggi tidak tercukupi. Tentu hal ini berpengaruh besar terhadap proses yang menyangkut dengan perawatan, perbaikan pesawat dan komponen penunjang permesinan yang ada di kapal. Hal ini peneliti temukan saat terjadi trouble pada pompa bahan bakar bertekanan tinggi pada tanggal 21 oktober 2016 saat kapal berlabuh di Tanjung Uban, ketika akan memperbaiki pompa bahan bakar bertekanan tinggi tersebut suku cadang komponen pompa tidak tersedia sehingga masinis mengorder (mengajukan permintaan) ke perusahaan. Hal ini akan membutuhkan waktu yang cukup lama untuk melakukan perbaikan kerusakan, karena perbaikan kerusakan itu harus mengganti komponen yang rusak dengan suku cadang yang baru. Komponen yang rusak dan harus diganti tersebut antara lain, delivery valve, delivery valve spring, plunger, dan plunger barrel.

Dari data yang telah dijelaskan sebelumnya, hasil analisa dari data tersebut diantaranya:

1. Terjadinya kerusakan pompa bahan bakar bertekanan tinggi pada motor bantu nomor 2 .

Pentingnya perawatan pada pesawat dan komponen penunjang guna menghindari terjadinya kerusakan pada alat-alat tersebut. Untuk itu perlu manajemen perawatan dan perbaikan pada pompa bahan bakar bertekanan tinggi yang perlu registrasi waktu, sistematika perencanaan perbaikan, arsip dan ketersediaan suku cadang. Namun pada kenyataannya apa yang Peneliti temukan di kapal tidaklah demikian. Dimana perawatan yang dilakukan pada pompa bahan bakar bertekanan tinggi dilakukan pada saat terjadinya trouble saja (perawatan insidentil).

Permasalahan terjadi akibat kurangnya perawatan pada pompa bahan bakar bertekanan tinggi antara lain; tidak dilakukannya pengecekan terhadap kondisi komponen pompa yang dapat berguna untuk memastikan secara tepat penyebab terjadinya penurunan tekanan dan tidak melaksanakan perawatan lainnya yaitu pengecekan dan pembersihan filter bahan bakar, serta pemeriksaan kualitas bahan bakar.

Kurang maksimalnya perawatan pada pompa bahan bakar bertekanan tinggi dapat mengakibatkan menurunnya kinerja dari pompa bahan bakar bertekanan tinggi tersebut, yang ditandai dengan menurunya tekanan bahkan tidak adanya bahan bakar yang masuk ke dalam silinder. Hal ini dapat dideteksi dari temperatur gas buang dapat dilihat pada termometer yang ada di setiap silinder. Rendahnya temperatur gas buang dapat dijadikan alternatif bahwa tekanan bahan bakar mengalami penurunan. Naik turunnya tekanan yang dihasilkan pompa sangat penting diketahui karena berkaitan dengan penyemprotan bahan bakar ke dalam silinder dalam bentuk halus (kabut). Seperti yang diketahui bahan bakar yang akan dibakar dalam proses pembakaran di silinder secara garis besar melalui penekanan dari pompa bahan bakar bertekanan tinggi, diteruskan melalui pipa bertekanan tinggi dan diteruskan lagi ke alat pengabut bahan bakar. Dengan kecepatan yang sangat tinggi agar dapat menembus udara yang mempunyai tekanan yang tinggi pula di dalam ruang kompresi silinder pada motor diesel.

2. Kurangnya ketersediaan suku cadang pompa bahan bakar bertekanan tinggi.

Suku cadang merupakan suatu bagian yang terpenting dari beberapa komponen semua permesinan diatas kapal ataupun kendaraan bermotor lainnya. Khususnya diatas kapal, suku cadang sangat penting keperluannya karena semua permesinan diatas kapal sangat membutuhkan pemeliharaan yang optimal untuk menjaga agar suatu mesin tetap berjalan normal dan tidak 
mengalami gangguan

Ketersediaan suku cadang yang cukup adalah salah satu faktor penting dalam suatu perawatan yang rutin dan terencana guna mendukung terlaksananya perawatan rutin tersebut. Jika ada suatu permasalahan tentang komponen pompa bahan bakar bertekanan tinggi yang harus segera diganti maka dengan adanya suku cadang tersebut dapat segera mengatasi masalah tanpa menunggu adanya kerusakan lain yang timbul akibat kerusakan yang tidak ditangani secara tepat.

Dalam permasalahan tentang ketersediannya suku cadang diatas kapal, peneliti sering kali menemukan banyak kekurangan tentang ketersediannya suku cadang tersebut seperti contoh masalah komponen suku cadang untuk pompa bahan bakar bertekanan tinggi saja banyak yang sudah tidak layak pakai alias rusak. Selain itu, banyak dari beberapa suku cadang pompa bahan bakar bertekanan tinggi tersebut dalam kondisi yang tambal sulam. Artinya, suku cadang tersebut diperoleh berdasarkan dari rekondisi komponen yang rusak kemudian diperbaiki dan diganti dengan komponen permesinan yang setipe lainya. Seperti contoh untuk suku cadang delivery valve, valve seat, plunger dan plunger barrel sehingga, untuk memperoleh suku cadang yang dalam kondisi baru terkadang sulit didapat.

Salah satu penyebabnya yaitu keterlambatan pengiriman suku cadang dari perusahaan kepada kapal yang bersangkutan tersebut, dimana permintaan diajukan pada tanggal 21 Oktober 2016 dan dipenuhi tanggal 25 Oktober 2016 sedangkan permintaan tersebut tiba di kapal pada 28 Oktober 2016. Hal ini disebabkan karena kurangnya koordinasi dari pihak kru kapal ke manajemen perusahaan, kurangnya koordinasi disebabkan oleh faktor kelalaian dari kru kapal sendiri yang seharusnya membuat daftar permintaan suku cadang secara rutin diminta untuk disetujui oleh KKM dan Nakhoda ke perusahaan pelayaran.

Selain faktor kelalaian dari pihak kru kapal, penyebab lain yaitu dari pihak perusahaan itu sendiri yang kurang perhatian terhadap suku cadang pada armada kapalnya. Karena untuk menyediakan suku cadang yang memadai maka dibutuhkan dana yang cukup besar bagi perusahaan. Jadi tidak mudah membeli dan menyediakan suku cadang dalam waktu yang singkat dan butuh waktu untuk menunggu bagi pihak kru kapal sampai suku cadang tiba.

Berdasarkan hasil analisa data terdapat beberapa hal yang dapat menimbulkan masalah yang terjadi pada pompa bahan bakar bertekanan tinggi, maka dibuat alternatif pemecahan masalah yang dapat dilakukan secara teknik operasional dalam hal ini pompa bahan bakar bertekanan tinggi adalah salah satu alat yang sangat perlu mendapat perhatian yang cukup serius.

1. Terjadinya kerusakan pompa bahan bakar bertekanan tinggi pada motor bantu nomor 2 .

Untuk mengatasi hal tersebut maka dibutuhkan suatu tindakan perbaikan agar kondisi pompa tetap dalam kondisi normal. Peneliti memberikan beberapa alternatif pemecahan masalah yang telah terjadi, sebagai berikut:

a. Pengecekan terhadap kondisi komponen pompa untuk memastikan penyebab utama dalam penurunan tekanan.

Untuk mengatasi kerusakan komponen pompa adalah melakukan perawatan dan perbaikan terhadap komponen pompa setelah dilakukan pengecekan melipti;

1) Keausan pada Plunger Barrel

bagian dari dalam pompa bahan bakar bertekanan tinggi tersebut adalah yang menekan bahan bakar sehingga mencapai tekanan kerja jika plunger tersebut aus atau longgar pada kedudukannya plunger barrel minyak begitu ditekan akan mengalir kesamping plunger barrel (lolos), dan jumlah minyak yang tidak seluruhnya ditekan ke pengabut bahan bakar, sehingga tekanan tidak mencapai tekanan kerja. (lampiran VIII dan IX)

2) Keausan pada delivery valve (katup tekan) dan delivery valve seat (rumah duduk katup tekan), bagian-bagian pompa tersebut tidak akan menutup dengan rapat atau baik karena terganjal dengan kotoran-kotoran dengan bahan bakar atau aus, setelah bahan bakar ditekan dari plunyer delivery valve membuka dan bahan bakar mengalir hingga plunyer kembali kebawah, minyak yang ada pada saluran pipa tekan ke pengabut akan kembali ke bawah, minyak yang ada pada saluran pipa tekan ke pengabut akan kembali masuk ke rumah plunyer melalui katup tekan tersebut sehingga terjadi kekosongan bahan bakar pada pipa tekanan terjadi penekanan bahan bakar kembali oleh plunger, bahan bakar hanya akan mengisi kekosongan pipa tekanan saja dan tidak dapat sepenuhnya menekan membuka jarum pengabut bahan bakar. (lampiran X)

3) Delivery valve spring (pegas katup tekan), jika pegas tersebut patah atau sudah lemah tidak dapat menekan kembali katup secara baik atau rapat pada kedudukan semula setelah katup tersebut membuka karena tekan bahan bakar. (lampiran X)

4) Plunger spring, jika pegas plunyer tersebut patah pada saat nok menekan, plunger dengan perantara pegas tersebut, pegas tidak dapat menekan secara sempurna sehingga plunger tidak dapat menekan secara sempurna sehingga plunger tidak dapat bekerja secara maksimal. (lampiran X) 
5) O ring pada delivery valve holder jika $\mathrm{O}^{\prime}$ ring tersebut rusak karena minyak akan keluar melalui katup rumah pompa (cover atas), karena O' ring tidak rapat (kedap) pada kedudukannya sehingga bahan bakar dengan mudah keluar melalui O' ring tersebut. (lampiran X)

6) Control sleeve jika terjadi kerusakan pada satu gigi dari control sleeve tersebut pada saat menarik batang rack yang disertai Control sleeve membuka saluran minyak pada plunyer karena Control sleeve tidak dapat bekerja dengan baik (kemungkinan akan membuka lebih besar atau kecil bahkan tidak sama sekali) karena macet maka jumlah bahan bakar akan ditekan oleh plunger atau yang akan masuk melalui alur pada plunyer tidak dapat diatur sehingga mempengaruhi hasil pembakaran bahan bakar di dalam silinder pada tiap pompa bahan bakar bertekanan tinggi dengan Control sleeve yang mengalami kerusakan.

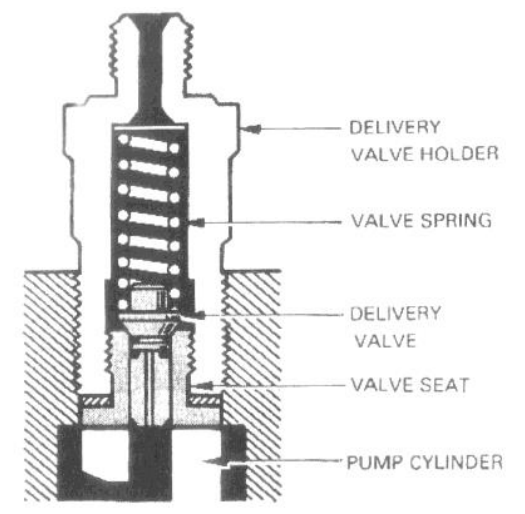

Gambar 1. Posisi tutup delivery

b. Alternatif kedua yaitu mengecek dan menjaga kevakuman pompa serta mencegah terjadinya kebocoran halus dari setiap O'ring.

Hal ini dilakukan untuk mencegah masuknya angin kedalam pompa bahan bakar bertekanan tinggi, ini menjadi salah satu penyebab terhambatnya proses penyemprotan bahan bakar ke dalam silinder dikarenakan suplai bahan bakar dari pompa bahan bakar bertekanan tinggi lebih banyak berisi angin dibandingkan dengan bahan bakar yang akan disalurkan, hal tersebut akibat dari kurang kedapnya gasket pada saluran inlet bahan bakar yang menuju kedalam pompa bahan bakar bertekanan tinggi, sehingga udara dari luar dapat masuk.

c. Alternatif ketiga yaitu pada pompa itu sendiri

Besar pengaruh keausan pada pompa bahan bakar bertekanan tinggi yang langsung bergesekan dengan bahan bakar karena adanya kotorankotoran yang terkait di dalam bahan bakar. Di dalam bahan bakar minyak yang dipakai motor diesel sebagian besar terdapat kadar belerang, sebagian molekul-molekul yang terikat pada zat $\mathrm{C}-\mathrm{H}$ sehingga tidak dapat dipisahkan lagi, dan terdapat kadar abu yang ada dalam minyak bumi kasar akan tetapi dapat juga terbawa pada saat pengangkutan atau proses bunkering.

Pada umumnya bahan bakar terbentuk seperti hydrocarbon yang terkontaminasi dengan nikel, vanadium, aluminium, besi dan natrium. Zat-zat tersebut dapat mengakibatkan terjadinya keausan dan korosi pada bahan yang bergesekan langsung dengan bahan bakar tersebut.

Untuk mencegah agar tidak terjadinya kerusakan komponen pompa dan kurang kedapnya pompa maka perlu juga meningkatkan perawatan dan perbaikan yang dilakukan pada pompa bahan bakar bertekanan tinggi sesuai dengan buku petunjuk dari pesawat tersebut sehingga kerusakan dari komponen pompa atau terjadinya kebocoran yang dapat mengakibatkan kurang kedapnya dapat dideteksi secepatnya, dan kinerja dari permesinan tersebut.

Perawatan berencana sangat dianjurkan untuk dilaksanakan dalam merawat permesinanpermesinan yang ada di kapal. Pada umumnya metode perawatan berencana bertujuan untuk memperkecil kerusakan dan beban kerja dari suatu pekerjaan dan perawatan yang diperlukan.

Adapun bentuk dari sistem perawatan berencana ini dapat dilihat dalam bentuk siklus sebagai berikut:

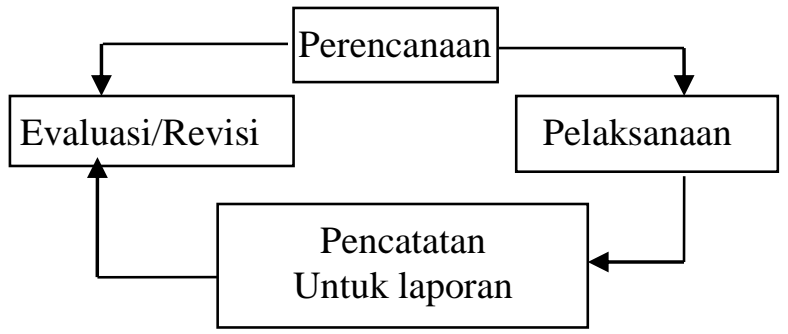

Gambar 2. Siklus Perawatan

Dari siklus di atas dapat disimpulkan bahwa pencatatan adalah cara yang baik untuk dilakukan analisa dan evaluasi terhadap suatu perawatan yang dilakukan. Pencatatan sendiri bertujuan untuk meningkatkan perencanaan perawatan di masa yang akan datang dengan membandingkan apa yang sudah pernah dilakukan. Karena awak kapal yang selalu bergantian.

Berikut hal-hal yang harus diperhatikan pada saat evaluasi dan memeriksa hasil perawatan:

1) Selama pekerjaan berlangsung kualitas hasil pekerjaan selalu diperiksa agar tidak terjadi pengulangan pekerjaan.

2) Bila terjadi penyimpangan atau masalah harus didiskusikan dengan masinis atau seorang ahli yang berwenang sesuai prosedur yang berlaku.

3) Semua kegiatan perawatan dan perbaikan harus dicatat dengan teliti dalam buku 
perawatan mesin bersangkutan dan diperkirakan jadwal perawatan selanjutnya.

4) Hasil pekerjaan diperiksa dengan seksama diakhir pekerjaan untuk meyakinkan sesuai dengan yang diharapkan.

2. Kurangnya ketersediaan suku cadang pompa bahan bakar bertekanan tinggi.

Kurangnya suplai suku cadang dapat mengakibatkan terhambatnya proses dari perawatan yang direncanakan atau berkala. Faktor tersebut diakibatkan oleh keterlambatan pengiriman suku cadang dari perusahaan kepada kapal, dan kurangnya koordinasi dari pihak kru kapal ke manajemen perusahaan. Untuk itu, diperlukan alternative pemecahan masalah untuk hal ini yaitu:

a. Membuat daftar permintaan suku cadang pompa bahan bakar bertekanan tinggi

Untuk mengatasi kekurangan suku cadang diatas kapal maka diperlukan untuk membuat daftar komponen pompa bahan bakar bertekanan tinggi yang akan diperlukan untuk penggantian suku cadang yang telah habis jam kerjanya serta untuk perawatan di kemudian hari bila terjadi kerusakan kembali atau habisnya masa pakai pada komponen pompa bahan bakar bertekanan tinggi tersebut.

Beberapa daftar dari permintaan suku cadang berikut ini yang diperlukan untuk penggantian komponen komponen seperti :

1) Delivery valve

2) Delivery valve spring

3) Delivery valve seat

4) Plunger

5) Plunger barrel

Dari beberapa komponen yang telah disebutkan diatas adalah sebagian dari komponen pompa bahan bakar bertekanan tinggi yang harus selalu diperhatikan kondisi dan masa jam kerjanya dari komponen tersebut. Jika komponen tersebut telah lewat dari masa jam kerjanya dan tidak segera dilakukan penggantian, maka dapat dipastikan akan mengganggu dari kinerja pompa bahan bakar bertekanan tinggi tersebut atau tidak beroperasi secara maksimal.

b. Menyampaikan jumlah atau daftar ketersediaan suku cadang, serta mengajukan permintaan suku cadang.

Dalam melaksanakan pola perawatan secara berkala tentunya harus sesuai dengan instruksi yang telah tercantum pada buku manual atau manual book pompa bahan bakar bertekanan tinggi tersebut. Oleh sebab itu peran dari ketersediaan suku cadang dalam mendukung kegiatan perawatan secara berkala ini sangatlah perlu dan mendesak. Untuk memperoleh suku cadang tersebut diperlukan adanya koordinasi antar pihak yaitu pihak kru kapal dan Masinis III dan pihak perusahaan sebagai pemilik dan penyedia dalam pengadaan suku cadang tersebut.

Dalam hal ini pihak kru kapal khususnya Masinis III sebaiknya menyampaikan data ketersediaan dan permintaan suku cadang yang diperlukan dalam perawatan jangka pendek dan selanjutnya atau jangka panjang.

Dari alternatif pemecahan masalah yang telah dijelaskan sebelumnya maka perlu dilakukan evaluasi pemecahan masalah diantaranya:

1. Terjadinya kerusakan pompa bahan bakar bertekanan tinggi pada motor bantu nomor 2 .

Pertama, perlu dilakukan pengecekan, perawatan dan perbaikan terhadap rumah pompa, perawatan, perbaikan terhadap plunger dan plunger barrel, perawatan dan perbaikan terhadap O'ring, perawatan, perbaikan terhadap deliverry valve, delivery valve spring dan delivery valve seat.

Adanya penurunan tekanan pada pompa bahan bakar bertekanan tinggi selanjutnya dilakukan perawatan dan perbaikan terhadap komponen penting pompa bahan bakar bertekanan tinggi. hal ini memiliki kelebihan dan kelemahan.

Kelebihan dari melaksanakan alternatif ini yaitu mengatasi penurunan tekanan pompa bahan bakar bertekanan tinggi dengan cara mengecek kondisi komponen pompa ini sangat efektif karena kita dapat memastikan bahwa terjadinya kerusakan ataupun kurangnya perawatan pada komponen pompa yang sangat berpengaruh terhadap kinerja pompa, terutama dalam hal ini penurunan tekanan aliran pompa bahan bakar bertekanan tinggi. disamping itu kita dapat mengetahui kondisi komponen pompa sehingga dapat mengetahui masa pakai dan dapat memperbaikinya jika terjadi kerusakan, maka pengaruh dari sisi komponen pompa terhadap penurunan tekanan dan kapasitas aliran pompa dapat diatasi.

Namun alternatif ini juga terdapat kelemahannya yaitu:

1) Waktu yang dibutuhkan lama untuk membongkar dan merakit kembali pompa dengan benar.

2) Perlu keterampilan khusus, konsentrasi dan ketelitian lebih dalam pengerjaan karena terdapat banyak komponen dalam pompa untuk menghindari kesalahan dalam perakitan sehingga tidak terjadi pembongkaran dan perakitan berulang kali.

3) Diperlukan peralatan khusus dan suku cadang yang memadai dalam pengerjaannya.

Kedua, mengecek dan menjaga kevakuman pompa serta mencegah terjadinya kebocoran halus pada rumah pompa. Seperti alternatif sebelumnya 
alternatif ini juga memiliki kelebihan dan kelemahan dalam pelaksanaannya.

Kelebihan dari alternatif ini yaitu tidak perlu dilakukan pembongkaran (overhaul) pada pompa sehingga pengerjaannya dapat dilakukan dengan cepat, tidak memerlukan suku cadang yang lengkap dan tidak memerlukan banyak tenaga kerja dalam proses pengerjaannya.

Sedangkan kelemahan dari alternatif ini adalah kondisi komponen-komponen dalam pompa (plunger, plunger barrel,delivery valve,dll) tidak diketahui karena tidak dilakukan pembongkaran (overhaul) terhadap pompa. Sehingga masalah atau kerusakan yang lain tidak dapat terdeteksi.

Ketiga, mengecek kualitas kebersihan bahan bakar yang dipompakan oleh pompa bahan bakar bertekan tinggi dengan memeriksa saringansaringan yang dilalui oleh sistem bahan bakar serta pengambilan sampel bahan bakar untuk dicek di laboratorium untuk mengetahui kualitas bahan bakar tersebut. Seperti alternatif pemecahan masalah yang lain alternatif ini juga memiliki kelebihan dan kelemahannya.

Kelebihan dari alternatif ini adalah perawatan yang dilakukan cukup mudah karena hanya melakukan pembersihan filter, memeriksa alatalat pembersih bahan bakar, dan mengambil sampel bahan bakar.

Namun kelemahannya adalah diperlukan waktu yang lama karena bahan bakar dapat diketahui kandungannya bersifat baik atau buruk sesuai dengan hasil dari laboratorium.

2. Kurangnya ketersediaan suku cadang pompa bahan bakar bertekanan tinggi.

Menjaga agar suku cadang selalu tersedia di atas kapal adalah bagian dari suatu keharusan dalam program perawatan secara berencana. Akan tetapi, perawatan berkala dapat terhambat apabila di atas kapal mengalami kekurangan suku cadang yang memadai. Berdasarkan hasil dari analisa dan ditemukannya alternative pemecahan masalah maka dapat dievaluasikan sebagai berikut:

Pertama, membuat daftar permintaan suku cadang komponen tertentu pada pompa bahan bakar bertekanan tinggi. Kelebihan dari cara ini yaitu dengan permintaan suku cadang yang hanya untuk komponen yang diperlukan saja maka dari pihak perusahaan sendiri lebih cepat dalam proses pengirimannya karena tidak banyak biaya yang harus dikeluarkan dalam jumlah yang besar sehingga pihak manajemen perusahaan sendiri lebih cepat menyetujui untuk mensuplai suku cadang tersebut.

Sedangkan kelemahannya adalah :

1) Suku cadang yang diperlukan hanya terpaku kepada komponen tertentu saja jika terjadi kerusakan pada komponen lain maka dipastikan komponen itu tidak memiliki suku cadang penggantinya.

2) Selain terpaku pada komponen tertentu, juga akan mengalami kehabisan dari suku cadang tersebut jika permintaan terbatas dan sedikit jumlahnya.

Kedua, menyampaikan jumlah atau daftar ketersediaan suku cadang, serta mengajukan permintaan suku cadang dari seluruh komponen pompa bahan bakar bertekanan tinggi untuk perawatan secara berkala.

Kelebihan dari cara ini adalah bagi kru kapal sendiri tidak perlu repot dalam mencari suku cadang tambahan jika akan dilakukan penggantian komponen ataupun dilakukan penggantian komponen ataupun melaksanakan perawatan dalam jangka panjang.

Kelemahan dari cara ini yaitu jika pihak kapal mengajukan permohonan atas suku cadang tersebut untuk seluruh komponen pompa bahan bakar bertekanan tinggi dan dalam jumlah besar maka dipastikan dari pihak perusahaan sendiri akan sulit melakukan pengiriman dalam waktu yang singkat dan tepat waktu sesuai dengan keinginan pihak kru kapal, sehingga diperlukan waktu yang cukup lama untuk mensuplai seluruh suku cadang kompresor karena biaya yang harus disediakan bagi pihak perusahaan cukup besar dan mahal.

Setelah dilakukannya evaluasi terhadap setiap alternatif pemecahan masalah yang telah dipaparkan sebelumnya, maka dapat ditentukan alternatif mana yang paling tepat utnuk dipilih sebagai pemecahan masalah, yaitu:

1. Terjadinya kerusakan pompa bahan bakar bertekanan tinggi pada motor bantu.

Dengan melakukan pertimbangan atas kelebihan dan kelemahan dari alternatif pertama, maka peneliti memilih alternatif pemecahan masalah yang pertama yaitu dengan melakukan pengecekan terlebih dahulu kondisi komponen pompa terhadap kerusakan dan keausan pada plunger, plunger barrel dan delivery valve seat sehingga dapat diketahui penyebab penurunan tekanan pompa bahan bakar bertekanan tinggi, kemudian melakukan perbaikan dan perawatan terhadap kondisi komponen pompa yang kurang baik sehingga kondisi normal pompa dapat tercapai. Langkah ini sangat efektif untuk mengatasi permasalahan yang diangkat oleh peneliti karena telah dipastikan komponen pompa sudah normal, kondisi pompa yang baik (normal) akan menghasilkan kinerja motor yang optimal pula.

2. Kurangnya ketersediaan suku cadang pompa bahan bakar bertekanan tinggi. 
Dari pihak kapal itu sendiri sebaiknya memeriksa tempat penyimpanan suku cadang apabila terdapat suku cadang yang kurang, maka Masinis tiga harus menyampaikan jumlah atau daftar ketersediaan suku cadang, serta mengajukan permintaan suku cadang dari seluruh komponen pompa bahan bakar bertekanan tinggi untuk perawatan secara berkala, karena cara demikian adalah sesuai dengan kebutuhan bagi pola perawatan dengan sistem berkala jangka panjang. Walaupun pihak kapal sendiri harus menunggu dalam waktu yang cukup lama untuk mendapatkan supply suku cadang secara keseluruhan dari pihak perusahaan.

\section{KESIMPULAN}

Dari hasil analisa diketahui penyebab timbulnya beberapa masalah yang terjadi, maka peneliti menyimpulkan sebagai berikut:

1. Terjadinya kerusakan pompa bahan bakar bertekanan tinggi pada motor bantu.

Terjadinya kerusakan pompa bahan bakar bertekanan tinggi diakibatkan oleh kurangnya perawatan. Kerusakan pompa bahan bakar bertekanan tinggi mengakibatkan turunnya kinerja dari pompa tersebut, sehingga terjadi penurunan tekanan bahan bakar yang masuk kedalam silinder yang menyebabkan tidak optimalnya kinerja dari motor bantu.

2. Kurangnya ketersediaan suku cadang pompa bahan bakar bertekanan tinggi.

Kurangnya ketersediaan suku cadang di atas kapal diakibatkan oleh keterlambatan pengiriman suku cadang dari perusahaan kepada kapal, dan kurangnya koordinasi dari pihak kapal dan perusahaan pemilik kapal.

Adapun saran yang dimaksud sebagai berikut:

1. Terjadinya kerusakan pompa bahan bakar bertekanan tinggi pada motor bantu.

Masinis yang bertanggung jawab (masinis III) sebaiknya melakukan evaluasi dalam waktu tertentu sehingga dapat mengetahui kondisi dari komponen pompa bahan bakar bertekanan tinggi yang kurang maksimal kinerjanya.

2. Kurangnya ketersediaan suku cadang pompa bahan bakar bertekanan tinggi.

Masinis yang bertanggung jawab terhadap suku cadang pompa bahan bakar bertekanan tinggi (masinis III) harus menyampaikan berita acara kerusakan, menyampaikan jumlah atau daftar ketersediaan suku cadang, serta mengajukan permintaan suku cadang dari seluruh komponen pompa bahan bakar bertekanan tinggi untuk perawatan secara berkala kepada perusahaan.

\section{DAFTAR PUSTAKA}

[1] Akademi Ilmu Pelayaran. 1976. Motor-Motor Diesel Kapal AIP. Jakarta.

[2] Arismunandar, Wiranto dan Tsuda, Koichi. 1975. Motor Diesel Putaran Tinggi. Jakarta: PT. Pranadya Paramita

[3] Atmaja, Suyatna B. 1990. Metodologi Penelitian Sosial. Bandung : FIP FKIP.

[4] Balai pustaka. 1994. Kamus Besar Bahasa Indonesia. Balai pustaka, Jakarta

[5] Daryus, A. 2008. Manajemen Pemeliharaan Mesin. Jakarta.

[6] Harahap, Nurdin. 2007. Mesin Penggerak Utama. Jakarta: Seaman Corp Technical Division, STIP

[7] Heizer, Jay., Render, Berry. 2001. Operation Management.

[8] Maanen, P. Van. (n.d). Motor Diesel Kapal Jilid 1. Nautech. Jakarta

[9] Marleev, V.L. 1995. Operasi Dan Pemeliharaan Mesin Diesel. PT. Gelora Aksara Pratama. Jakarta.

[10] Morton, Thomas D. 1975. Reed' Motor Engineering Knowledge For Marine Engineer. Grand Books \& Records CO. Taiwan

[11] NSOS. 1985. Manajemen Perawatan dan Perbaikan. Jakarta.

[12] Rabiman dan Arifin, Zainal. 2011. Sistem Bahan Bakar Motor Diesel. Yogyakarta.

[13] Salim, Abbas. 2006. Manajemen Transportasi. Raja Grafindo, Jakarta.

[14] Sehwarat, M.S dan Narang, J.S. 2001. Production Management.

[15] Sukoco dan Arifin, Zainal. 2008. Teknologi Motor Diesel. Alfabeta. Bandung.

[16] Tamin, Ofyar Z. 2000. Perencanaan dan Permodelan Transportasi. Bandung: Institut Teknologi Bandung.

[17] Undang- Undang RI No. 17 Tahun 2008 Tentang Pelayaran. 